
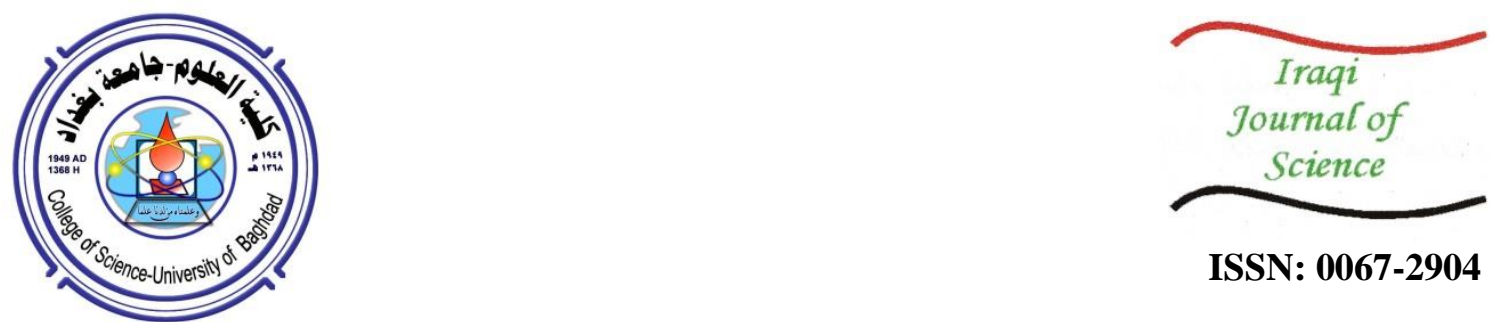

ISSN: 0067-2904

\title{
Serum Level of Interleukin-35 in Patients with Chronic Hepatitis B Virus Infection
}

\author{
Rana T. Mohsen ${ }^{1}$, Raghad H. Al-azzawi ${ }^{2}$, Ali H. Ad'hiah ${ }^{3 *}$ \\ ${ }^{1}$ Department of Biotechnology, College of Science, University of Anbar, Al-Anbar, Iraq \\ ${ }^{2}$ Department of Biology, College of Science, University of Baghdad, Baghdad, Iraq \\ ${ }^{3}$ Tropical-Biological Research Unit, College of Science, University of Baghdad, Baghdad, Iraq
}

Received: $23 / 2 / 2020$

Accepted: 9/5/2020

\begin{abstract}
Interleukin-35 (IL-35) is a new member of IL-12 family of cytokines, and its role in pathogenesis of hepatitis B virus (HBV) infection has been recently suggested. Accordingly, a case-control study was conducted during June - October 2018 to determine IL-35 serum level in Iraqi patients with chronic HBV infection. The results revealed that IL-35 level was significantly decreased in patients as compared to control (163 vs. $301 \mathrm{pg} / \mathrm{ml} ; p<0.001)$. However, such decreased level was more pronounced in patients at the age groups $<40$ and $40-50$ years (165 and $145 \mathrm{pg} / \mathrm{ml}$, respectively) as compared to the corresponding age groups in control (482 and $234 \mathrm{pg} / \mathrm{ml}$, respectively). In the case of gender groups, both male and female patients showed a significantly decreased level of IL-35 compared to the corresponding control groups (163 and 163 vs. 306 and $297 \mathrm{pg} / \mathrm{ml} ; p=0.004$ and 0.001 , respectively). Distributing HBV patients and control according to medians of IL-35 ( $\leq$ median and $>$ median) revealed that $67.5 \%$ of patients had $\leq$ median compared to $35.4 \%$ among control. Such difference was significant $(p<0.001)$, with a scored odds ratio (OR) of 3.79. Receiver operating characteristic (ROC) analysis revealed that the decreased level of IL-35 occupied an area under curve (AUC) of 0.710 , which was highly significant $(p<0.001)$. At a cut-value of $188 \mathrm{pg} / \mathrm{ml}$ or lower, the diagnostic sensitivity and specificity were 67.7 and $66.2 \%$, respectively. In conclusion, these results confirmed the role of IL-35 in the pathogenesis of HBV.
\end{abstract}

Keywords: Hepatitis B virus; Intereukin-35; Sensitivity; Specificity.

\section{المستوى المصلي للبين ابيضاض -35 في مرضى خمج الكبد الفايروسي المزمن نوع}

$$
\begin{aligned}
& \text { رنا طالب محسن } 1 \text { و رغد حربي العزاوي² و علي حسين ادحية3،" }
\end{aligned}
$$

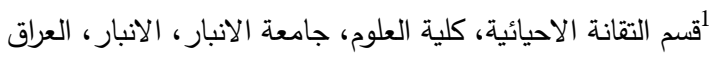

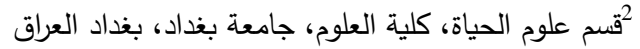

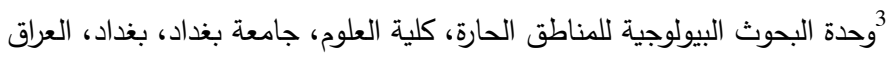

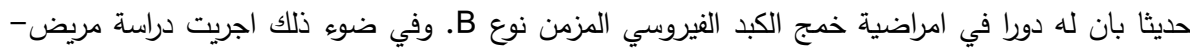

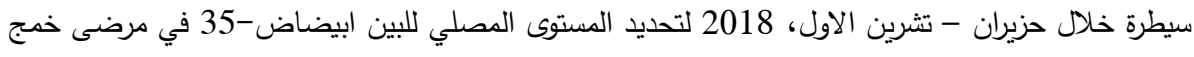

$$
\begin{aligned}
& \text { الكبد الفايروسي المزمن نوع B العراقيين. اظهرت النتائج انخفاض معنوي في المستوى المصلي للبين }
\end{aligned}
$$

$\overline{\text { *Email: dr.a.h.adhiah@gmail.com }}$ 


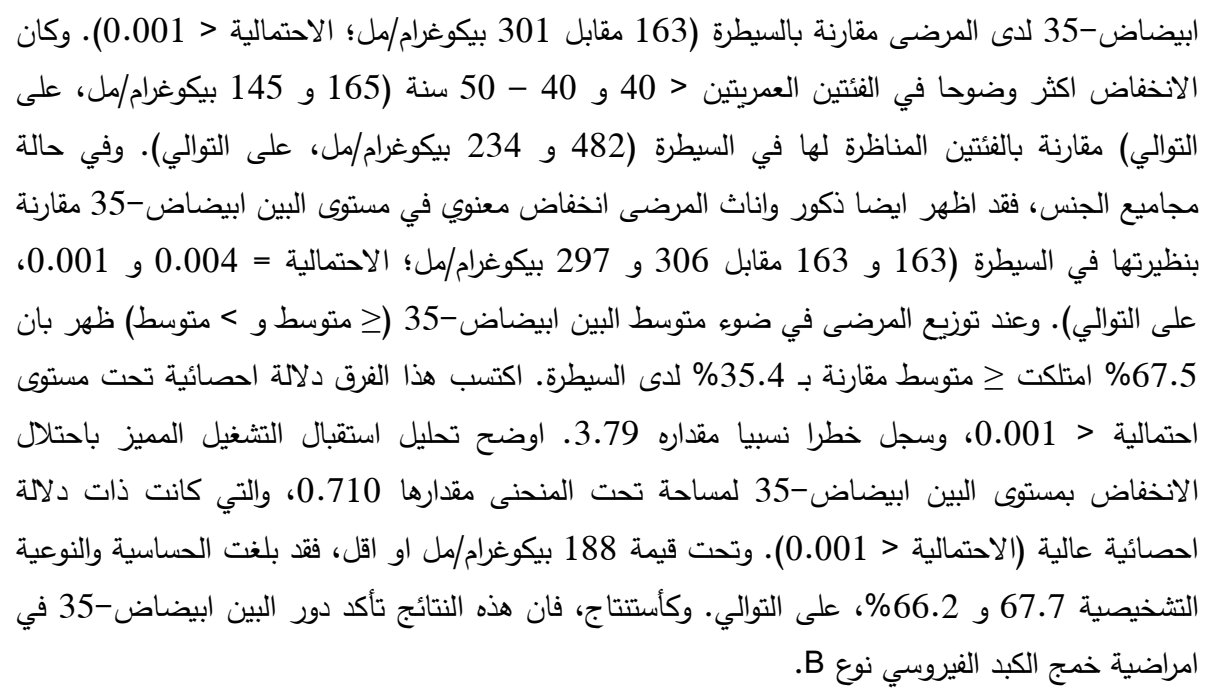

\section{Introduction}

Hepatitis B virus (HBV) infection is a global health challenge. It has been estimated that 257 millions of humans are infected with the virus, resulting in an estimated annual mortality of 887,000 due to liver cirrhosis and/or hepatocellular carcinoma [1, 2, 3]. In Iraq, a community-based study reported a prevalence of $1.6 \%$ for hepatitis B surface antigen (HBsAg). Further, the anti-hepatitis B core antigen $(\mathrm{HBc})$ and anti-HBs antibodies were reported at prevalence of 9.7 and $17 \%$, respectively [4]. Accordingly, the endemicity of HBV in Iraq was considered to be at low / intermediate level.

Clearance or persistence of HBV infection is mostly determined by host immune responses. A complex interaction between HBV and an inadequate immune response is required to establish the chronicity of HBV infection [5]. Upon infection, effective antiviral immune responses mediated by $\mathrm{CD} 8+$ and CD4+ T cells, as well as natural killer (NK) cells and monocytes, can result in partial or complete eradication of HBV [6]. It has been demonstrated that acute HBV infection induces CD4+ and $\mathrm{CD} 8+\mathrm{T}$ responses together with elevated production of interferon-gamma (IFN- $\gamma$ ). IFN- $\gamma$ is prominent cytokine in clearing the virus and controlling HBV infection [7]. In contrast, increased production of inhibitory cytokines, for instance interleukin 10 (IL-10) and transforming growth factorbeta (TGF- $\beta$ ), has been associated with persistent HBV infection and inability to eradicate the virus due to a down-regulation of $\mathrm{T}$ cells [8]. Recently, a further cytokine (IL-35) has been suggested to play a role in maintaining viral persistence.

IL-35 is the latest member of IL-12 family, which is recognized to have anti-inflammatory and immunosuppressive properties [9]. It is a heterodiemeric cytokine that consists of two subunits; IL$12 \alpha$ chain p35 (IL-12p35) and IL-27 $\beta$ chain Epstein-Barr virus-induced 3 (EBI3) [10]. Several cells have been reported to produce IL-35, including stimulated natural T regulatory (Treg) cells, IL35producing regulatory B cell (i35-Breg) and stimulated pan $\mathrm{T}$ cells [11]. Two distinct immunological functions are linked to IL-35; suppression of T cells proliferation and transformation of these cells into Treg cells [12]. Due to these functions, abnormal regulation of IL-35 has been suggested to have a prominent role in immune-associated diseases; for instance autoimmune diseases, cancer and viral and bacterial infections [13]. In HBV, recent studies suggest a critical immune-pathogenic role for IL-35 in potentiating a chronic infection $[14,15]$.

In line with these findings, the present study aimed to determine serum level of IL-35 in HBV patients and correlate such level with age and gender of patients.

\section{Materials and Methods}

\section{Patients and control}

A case-control study was conducted during June-October 2018 to assess IL-35 serum level in Iraqi patients with chronic HBV infection. The Ethics Committee at the Department of Biology (University of Baghdad) approved the study protocol (Reference: BEC/1019/002). Eighty cases (50 males and 30 females) with chronic HBV infection were recruited from the Specialized Center for Gastroenterology and Hepatology (SCGH) in Baghdad. The WHO and European Association for the Study of the Liver (EASL) guidelines on HBV testing were followed $[16,17]$. Accordingly, anti-HBc (hepatitis B core antigen), IgM, $-\mathrm{HBc}$ IgG and -HbsAg (hepatitis B surface antigen) antibodies were determined. A 
control sample of 96 healthy blood donors (58 males and 38 females) was also included. Their serum status for the antibody profile at the Central Blood Bank (Baghdad) was negative. The age mean \pm standard values of patients and control were $40.7 \pm 13.8$ and $43.6 \pm 11.8$ years, respectively

\section{Laboratory methods}

Three enzyme-linked immunosorbent assay (ELISA) kits were used for qualitative assessments of anti-HBV antibodies in sera of patients and control (anti-HBc IgM, - $\mathrm{HBc}$ IgG and -HbsAg antibodies). The kits were products of MyBioSource Company (USA). Serum level of IL-35 was determined using a kit produced by Abbexa Ltd (Cambridge, UK). The kit was based on a sandwich ELISA technology. Standard procedures recommended by the manufacturers were followed in these assessments.

\section{Statistical analysis}

Serum level of IL-18 in patients and control was first tested for normality (Kolmogorov-Smirnov and Shapiro-Wilk tests), and normal distribution was not ascertained. Therefore, the level was given as median and range. Significant differences between medians were assessed by two non-parametric tests; Mann-Whitney U (for comparison between two groups) and Kruskal-Wallis (for comparison between more than two groups). The odds ratio (OR) was estimated in relation to IL-35 median (> and $\leq$ median) in patients and control. Receiver operating characteristic (ROC) analysis was carried out to determine the area under curve (AUC), sensitivity and specificity of IL-35. A $p$-value $\leq 0.05$ was considered significant. The statistical package SPSS (version 19.0) was employed to perform these analyses.

\section{Results and Discussion}

This study is a part of a larger project, the first part of which included the study of hepatitis B virus genotypes by the analysis of HBV-DNA, where the PCR products revealed six genotypes (A, B, C, D, $\mathrm{E}$ and $\mathrm{F}$ ) which showed different frequencies in HBV patients [18] . The current study of serum assessments for anti-HBc IgM, - HBc IgG and -HbsAg antibodies revealed that all HBV patients were seropositive for anti-HBc IgG and -HbsAg antibodies, while they were seronegative for anti-HBc IgM antibody. Such profile was compatible with the diagnosis of chronic HBV infection [19]. With respect to control, all participants were seronegative for the tested antibodies.

Serum level of IL-35 was significantly decreased in chronic HBV patients compared to control (163 vs. $301 \mathrm{pg} / \mathrm{ml} ; p<0.001$ ) (Figure-1). However, such decreased level was more pronounced in patients at the age groups < 40 and $40-50$ years ( 165 and $145 \mathrm{pg} / \mathrm{ml}$, respectively) compared to the corresponding age groups in control (482 and $234 \mathrm{pg} / \mathrm{ml}$, respectively). Whereas, IL-35 serum level showed no significant variation between patients and control at the age group > 50 year $(164 v s .209$ $\mathrm{pg} / \mathrm{ml} ; p=0.167)$. It is also worthy to mention that IL-35 level showed a gradual decrease as age was progressing from $<40$ years to $>50$ years in the control group, with the differences being significant (482, 234 and $209 \mathrm{pg} / \mathrm{ml}$, respectively; $p$ 0.010). No Such variation was observed among patients (Table-1).

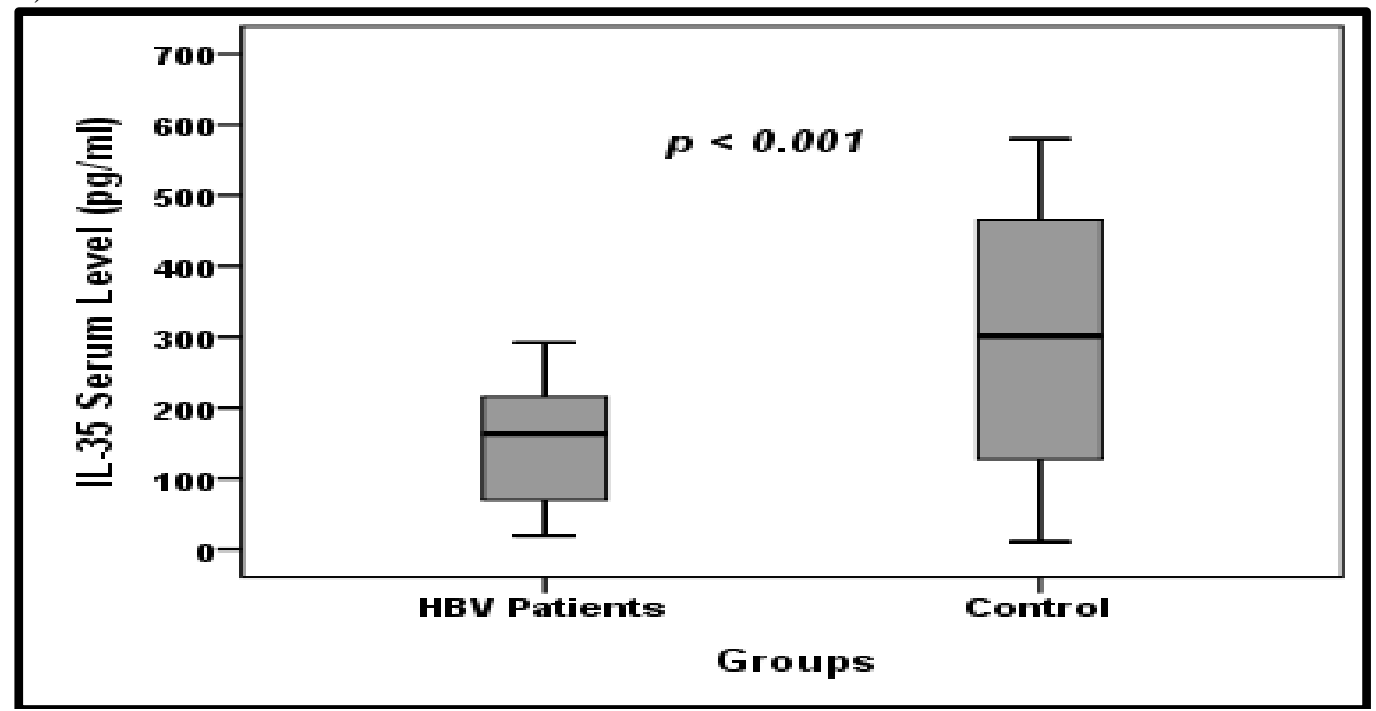

Figure 1-Box-plot presentation of IL-35 level in sera of hepatitis B virus infection patients and control. 
Table 1-Median level of IL-35 in sera of hepatitis B virus infected patients and control, distributed according to age groups.

\begin{tabular}{|c|c|c|c|}
\hline \multirow{2}{*}{$\begin{array}{c}\text { Age Group } \\
\text { (year) }\end{array}$} & \multicolumn{2}{|c|}{ IL-35 Median (Range) $; \mathrm{pg} / \mathrm{ml}$} & \multirow{2}{*}{$P$} \\
\cline { 2 - 3 } & HBV patients & Control & $<\mathbf{0 . 0 0 1}$ \\
\hline$<40$ & $165(28-492)$ & $482(11-2806)$ & $\mathbf{0 . 0 0 7}$ \\
\hline $40-50$ & $145(19-674)$ & $234(29-2364)$ & $0.167(\mathrm{NS})$ \\
\hline$>50$ & $164(23-564)$ & $209(21-3140)$ & \\
\hline$p$ & $0.681(\mathrm{NS})$ & $\mathbf{0 . 0 1 0}$ & \\
\hline
\end{tabular}

$p$ : Probability; NS: Not significant $(p>0.05)$.

In the case of gender groups, both male and female patients showed a significantly decreased level of IL-35 compared to the corresponding control groups (163 and $163 v s .306$ and $297 \mathrm{pg} / \mathrm{ml} ; p=0.004$ and 0.001 , respectively). However, there was no significant gender-associated variation among patients or control (Table-2).

Table 2-Median level of IL-35 in sera of hepatitis B virus infected patients and control, distributed according to gender.

\begin{tabular}{|c|c|c|c|}
\hline \multirow{2}{*}{ Gender Group } & \multicolumn{2}{|c|}{ IL-35 Median (Range); $\mathrm{pg} / \mathrm{ml}$} & \multirow{2}{*}{$P$} \\
\cline { 2 - 3 } & HBV patients & Control & $\mathbf{0 . 0 0 4}$ \\
\hline Male & $163(19-674)$ & $306(11-3140)$ & $\mathbf{0 . 0 0 1}$ \\
\hline Female & $163(23-564)$ & $297(21-2364)$ & \\
\hline$p$ & $0.893(\mathrm{NS})$ & $0.650(\mathrm{NS})$ & \\
\hline
\end{tabular}

$p$ : Probability; NS: Not significant $(p>0.05)$.

Distributing HBV patients and control according to medians of IL-35 ( $\leq$ median and $>$ median) revealed that $67.5 \%$ of patients had $\leq$ median compared to $35.4 \%$ among control. Such difference was significant $(p<0.001)$, with an OR value of 3.79 (Table-3).

Table 3-Distribution of IL-35 serum levels ( $\leq$ median and $>$ median) in hepatitis B virus infected patients and control.

\begin{tabular}{|c|c|c|c|c|c|c|c|}
\hline \multirow{2}{*}{$\begin{array}{c}\text { IL-35 Level } \\
(\mathrm{pg} / \mathrm{ml})\end{array}$} & \multicolumn{2}{|c|}{ HBV Patients $(\mathrm{N}=80)$} & \multicolumn{2}{|c|}{ Control $(\mathrm{N}=96)$} & \multirow{2}{*}{ OR } & \multirow{2}{*}{$95 \% \mathrm{CI}$} & \multirow{2}{*}{$P$} \\
\cline { 2 - 5 } & $\mathrm{N}$ & $\%$ & $\mathrm{~N}$ & $\%$ & & \multirow{2}{*}{$2.03-7.07$} & $\mathbf{0 . 0 0 1}$ \\
\hline$\leq$ Median & 54 & 67.5 & 34 & 35.4 & \multirow{2}{*}{3.79} & 2.03 \\
\hline > Median & 26 & 32.5 & 62 & 64.6 & & \\
\hline
\end{tabular}

OR: Odds ratio; CI: Confidence interval; $p$ : Probability.

ROC analysis revealed that the decreased level of IL-35 in the sera of HBV patients occupied an AUC of 0.710 (95\% CI: $0.633-0.787)$, which was highly significant $(p<0.001)$. At a cut-value of $188 \mathrm{pg} / \mathrm{ml}$ or lower, the diagnostic sensitivity and specificity were 67.7 and $66.2 \%$, respectively (Figure-2).

The presented results demonstrated clearly that IL-35 was down-regulated in the present sample of Iraqi HBV patients. Therefore, an immunepathogenic mechanism involving IL-35 is suggested in the development of HBV infection. In this context, it is generally proposed that host mediated immune reactions play a prominent role in viral control and liver damage due to HBV infection [20]. Cytokines have been demonstrated to mediate these reactions, including IL-12 family of cytokines. The family encompasses five cytokines; IL-6, IL-12, IL-23, IL-27 and IL-35, which have been reported to play a vital role in the development of $\operatorname{HBV}[6,21,22]$ and other infections [23]. IL-35 is a newly described cytokine in this family, but its role in HBV infection has not been well-investigated. In agreement with the results of the present study, it has been recently demonstrated that serum levels of IL-35 and IL-35 were significantly decreased in chronic HBV infection patients, and the authors suggested a possible role of IL-35 in HBV infection [14]. Therefore, an abnormal regulation of IL-35 in the peripheral blood of HBV patients is suggested, but no clear mechanism has been delineated to explain the decreased serum level of IL-35 in patients. Therefore, further studies are certainly required to shed light on IL-35 role in immunopathogenesis of HBV, especially those based on gene expression of both IL-35 subunits. 


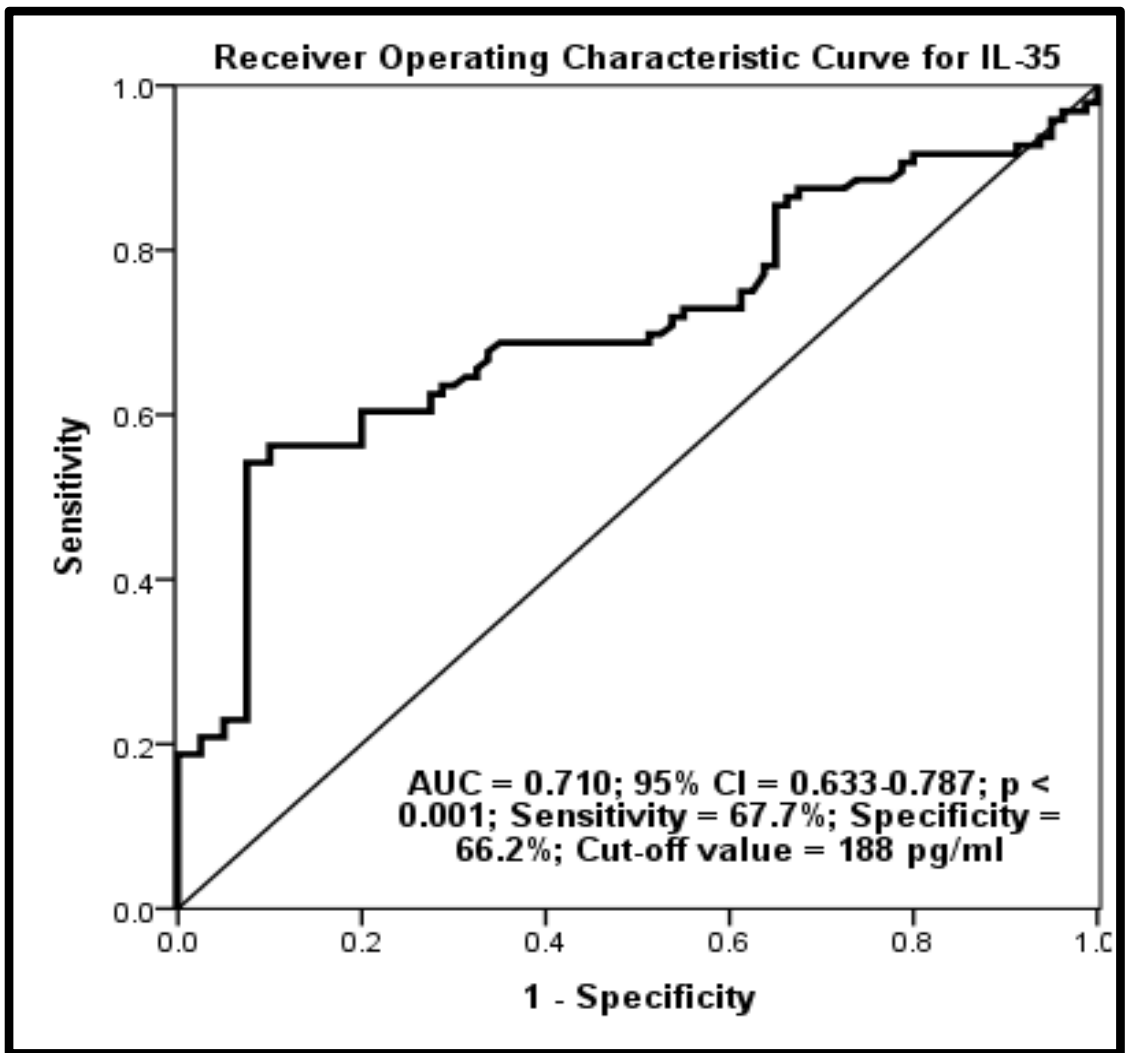

Figure 2-Receiver operating characteristic (ROC) analysis of IL-35 decreased serum level in HBV patients (AUC: Area under curve; CI: Confidence interval; $p$ : Probability).

\section{References}

1. Schweitzer A, Horn J, Mikolajczyk RT, Krause G. and Ott JJ .2015 Estimations of worldwide prevalence of chronic hepatitis B virus infection: a systematic review of data published between 1965 and 2013,Lancet, 386: 1546-1555

2. WHO. 2017 Global hepatitis report, 2017.

3. Qassim, R., Utba, N.M. and Abdulgader, T. 2016.The Role of Toll Like Receptor-2in hepatitis B infection, Iraqi Journal of Science, 57: 1383-1390.

4. Tarky AM, Akram W, Al-Naaimi AS. And Omer AR. 2013. Epidemiology of viral hepatitis B and C in Iraq: a national survey 2005-2006. Zanco ,J Med Sci, 17: 370-380

5. Li H-J, Zhai N-C, Song H-X, Yang Y, Cui A, Li T-Y. and Tu Z-K .2015. The Role of Immune Cells in Chronic HBV Infection,J Clin Transl Hepatol, 3: 277-83

6. Peeridogaheh H, Meshkat Z, Habibzadeh S, Arzanlou M, Shahi JM, Rostami S, Gerayli S, Teimourpour R .2018. Current concepts on immunopathogenesis of hepatitis B virus infection, Virus Res, 245: 29-43

7. Sandhu P, Haque M, Humphries-Bickley T, Ravi S. and Song J. 2017. Hepatitis B Virus Immunopathology, Model Systems, and Current Therapies, Front Immunol, 8: 436.

8. Maini MK. And Pallett LJ. 2018. Defective T-cell immunity in hepatitis B virus infection: why therapeutic vaccination needs a helping hand. Lancet Gastroenterol Hepatol, 3: 192-202

9. Su L-C, Liu X-Y, Huang A-F. and Xu W-D. 2018. Emerging role of IL-35 in inflammatory autoimmune diseases, Autoimmun Rev, 17: 665-673

10. Song M. and Ma X .2016. The Immunobiology of Interleukin-35 and Its Regulation and Gene Expression, Adv Exp Med Biol, 941: 213-225

11. Xue W, Yan D. and Kan Q .2019. Interleukin-35 as an Emerging Player in Tumor Microenvironment, J Cancer, 10: 2074-2082

12. Collison LW, Chaturvedi V, Henderson AL, et al .2010. IL-35-mediated induction of a potent regulatory T cell population,Nat Immunol, 11: 1093-101

13. Zhang J, Zhang Y, Wang Q, Li C, Deng H, Si C. and Xiong H . 2019. Interleukin-35 in immunerelated diseases: protection or destruction, Immunology, 157: 13-20. 
14. Shi M, Wei J, Dong J, Meng W, Ma J, Wang T, Wang N. and Wang Y. 2015. Function of interleukin-17 and -35 in the blood of patients with hepatitis B-related liver cirrhosis, Mol Med Rep, 11: 121-126

15. Shao X, Ma J, Jia S, Yang L, Wang W. and Jin Z. 2017. Interleukin-35 Suppresses Antiviral Immune Response in Chronic Hepatitis B Virus Infection,Front Cell Infect Microbiol, 7: 472.

16. Tao N-N, Gong R, Chen X, He L, Ren F, Yu H-B, Chen J, Ren J-H .2018. Interleukin-35 stimulates hepatitis B virus transcription and replication by targeting transcription factor $\mathrm{HNF} 4 \alpha, J$ Gen Virol, 99: 645-654

17. Cheng ST, Yuan D, Liu Y, Huang Y, Chen X, Yu HB, He L, Jiang H, Ren JH. And Chen J .2018. Interleukin-35 level is reduced in patients with chronic hepatitis B virus infection, Int J Med Sci, 15: 188-194.

18. Mohsen R.T, Al-azzawi R.H. and Ad'hiah, A.H. 2019.Hepatitis B virus genotypes among chronic hepatitis B patients from Baghdad, Iraq and their impact on liver function, Gene Reports 17 100548.

19. Tseng T-C. and Huang L-R. 2017. Immunopathogenesis of Hepatitis B Virus, J Infect Dis, 216: S765-S770.

20. Ramamurthy N, Boninsegna S, Adams R, Sahgal N, Lockstone H, Baban D, Marchi E. and Klenerman P.2016. Impact of IL-27 on hepatocyte antiviral gene expression and function, Wellcome Open Res, 1: 17.

21. Wang XF, Shi XH, Xu XX, et al. 2017. Effect of interleukin-6 and interleukin-12 on immune response to hepatitis B vaccination in infants of HBsAg-positive mothers, Zhonghua Liu Xing Bing Xиe Za Zhi, 38: 950-953

22. Yang L, Shao X, Jia S, Zhang Q. and Jin Z. 2019. Interleukin-35 Dampens CD8+ T Cells Activity in Patients With Non-viral Hepatitis-Related Hepatocellular Carcinoma, Front Immunol, 10: 1032.

23. Alkhanak Y R., Alwachi S N. and Zghair K H. 2015. The Effect of Toxoplasmosis Infection on Interleukin-12Level During Human Maturity in Baghdad Province, Iraqi Journal of Science 56(1B): 356-360. 